\title{
Archaeology at the Crossroads between the Humanities and Natural Sciences
}

\section{V.S. Bochkarev}

For citation: Bochkarev V.S. Archaeology at the Crossroads between the Humanities and Natural Sciences. Vestnik of Saint Petersburg University. History, 2021, vol. 66, issue 2, pp. 516-530. https://doi.org/10.21638/11701/spbu02.2021.212

In this study archaeological sites are defined as objects comprised of two major components. One of them is regarded as culturological, and the other one - as natural-historical. The first component is mainly represented by the artefacts, and thus it supplies cultural-historical information, examination and interpretation of which is one of the primary tasks of archaeology as a discipline of the humanities. The second component includes eco-facts, nature-facts and so-called cultural-natural objects. All of them have natural origin or were shaped under a strong influence of the natural environment, which makes it reasonable to deem this second component the basis for natural-scientific repository of archaeology. It provides materials for geological, palaeobotanical, palaeozoological, chemical and other researches. It must be strongly emphasized that such knowledge without a cultural-historical context has no purpose or focus. This article demonstrates that the natural-historical component is an integral part of any archaeological site. It is inseparable from the culturological component. A vivid material embodiment of the link between the two is provided by the cultural layer. Essentially,

Vadim S. Bochkarev - Senior Researcher, Institute for the History of Material Culture of the Russian Academy of Sciences, 18, Dvortsovaya nab., St. Petersburg, 191186, Russian Federation; Senior Lecturer, St. Petersburg State University, 7-9, Universitetskaya nab., St. Petersburg, 199034, Russian Federation; bovad872@gmail.com

Вадим Сергеевич Бочкарев - ст. науч. сотр., Институт истории материальной культуры РАН, Российская Федерация, 191186, Санкт-Петербург, Дворцовая наб., 18; ст. преп., Санкт-Петербургский государственный университет, Российская Федерация, 199034, Санкт-Петербург, Университетская наб., 7-9; bovad872@gmail.com

The study had been supported by the Federal Scientific Research Programme of the State Academy of Sciences, project no. 0184-2019-0004.

Работа проведена в рамках реализации ФНИ ГАН по теме государственного задания № 01842019-0004.

(C) St. Petersburg State University, 2021 
it is impossible to meaningfully examine the two components in isolation - independently of each other. As a result, the actual material archeologists work with, its content and character place archaeology at the crossroads between the humanities and natural sciences. It is hoped that in the future it will develop as a multi-disciplinary subject with a prevalence of the humanitarian dimension.

Keywords: essence of archaeological sites, cultural-historical and natural-historical components of archaeological sites, archaeology as a multi-disciplinary subject.

\section{Археология на перекрестке гуманитарного и естественно-научного знания}

\section{В. С. Бочкарев}

Для цитирования: Bochkarev V.S. Archaeology at the Crossroads between the Humanities and Natural Sciences // Вестник Санкт-Петербургского университета. История. 2021. Т.66. Вып. 2. C.516-530. https://doi.org/10.21638/11701/spbu02.2021.212

Как следует из принятой в статье дефиниции, археологические памятники состоят из двух основных компонентов. Один из них можно назвать культурологическим, а другой - природоведческим. Первый компонент представлен главным образом артефактами, поэтому он является основным поставщиком культурно-исторической информации, извлечение и изучение которой являются одной из главных задач археологии как гуманитарной дисциплины. Во второй компонент входят экофакты, натурфакты и так называемые культурно-природные объекты. Все они имеют природное происхождение или же сформировались под сильным воздействием окружающей среды, поэтому вполне обоснованно второй компонент можно рассматривать как основу естественно-научного фонда археологии. Из этого фонда отбираются материалы для геологических, палеоботанических, палеозоологических, химических и прочих естественно-научных исследований. Вместе с тем следует решительно подчеркнуть, что сами по себе, без культурно-исторического контекста, эти знания мало что значат. В отрыве от него они остаются безадресными и невостребованными. Они приобретают настоящую ценность и культурно-историческую значимость только в рамках этого контекста. На всех этапах своего развития и во всех своих подразделениях археология была и остается гуманитарной дисциплиной, так как основной ее целью является изучение прошлого человечества. Вместе с тем с первых своих шагов она начала использовать результаты естественно-научных анализов в своих материалах. В статье показано, что природоведческий компонент является неотъемлемой частью любого археологического памятника. Он неразрывно связан с другим компонентом - культурологическим. Ярким материальным воплощением их единства является культурный слой. В сущности, их невозможно полноценно исследовать изолированно друг от друга. Таким образом, сам материал, его содержание и характер отводят археологии место на стыке гуманитарного и естественно-научного знания. Надо полагать, что в дальнейшем она будет развиваться как комплексная дисциплина с преобладанием гуманитарного начала.

Ключевые слова: сущность археологических памятников, культурно-исторический и природоведческий компоненты, компоненты археологических памятников, археология как комплексная наука.

Recent successes in genetics in the study of the gene pool of the prehistoric population of Northern Eurasia ${ }^{1}$ have had a powerful and far from uniform impact on the

1 Haak W., Lazaridis I., Patterson N. et al. Population genomics of Bronze Age Eurasia // Nature. 2015. Vol.552. P. 167-172; Allentoft M. E., Sikora M., Sjögren K.-G. et al. Population genomics of Bronze Age 
archaeological community ${ }^{2}$. The results obtained by the geneticists have obliged archaeologists, in a number of cases, to reconsider their long-held ideas and to take a new look at certain aspects of cultural-historical development. This has led certain scholars to predict that sooner or later genetics (the study of paleo-genomes) will play as important role in archaeology as radiochemistry does. Both sciences, together with other scientific disciplines, have the potential to transform archaeology to such an extent that it will cease to be regarded as one of the humanities. Its future development will depend almost entirely on the advance of the natural sciences. All these events and the discussions following from them raise questions of the relationship and collaboration between archaeology and other disciplines, in particular, the natural sciences.

The movement of archaeology in the direction of the natural sciences is - in the opinion of Kristian Kristiansen - a logical process shaped by history ${ }^{3}$. According to the data he cites, the very emergence of archaeology, took place very much under the influence of geology and biology. From the former it adopted the concept of levels - the stratigraphic method, while from the latter it borrowed models for the classification of material, the idea of evolution and so on. This led to the first natural-scientific revolution in archaeology. The next revolution took place in the middle of the $20^{\text {th }}$ century, when the radio-carbon (C14) dating method was discovered. It literally did away with traditional chronology based on the Neolithic and Chalcolithic periods and the Bronze Age in Northern Eurasia. This new method led researchers significantly further back in time and gave rise to a fundamental re-evaluation of certain archaeological concepts. The third revolution - as Kristiansen points out - has already been set in motion. Decoding genomes and interpreting DNA will bring about no less of a sea change in archaeology than C14. In his opinion, our views on heredity within ancient populations and their migrations and also on cultural genesis in general will change completely. In the final analysis this will lead archaeology to a new paradigm, in which knowledge from the realm of the natural sciences will predominate. The intervals between the above-mentioned revolutions Kristian Kristiansen defines as periods of romanticism, in which the cultural-historical approach predominated.

The stance adopted by Kristian Kristiansen sent shock waves through the archaeological world. It provoked far-reaching discussion in the pages of Norwegian Archaeological Review $^{4}$ and was duly commented on in the Russian academic literature by L.S. Klein ${ }^{5}$, who also expressed his opinion on all the matters raised in the discussion.

The views of those taking part in deliberations diverged, as was only to be expected. The archaeologist, who came out most strongly against Kristian Kristiansen, was his fellow Dane, Tim-Flohr Sørensen ${ }^{6}$. He does not deny that archaeology has long been availing itself of data from the natural sciences, and successfully so. Yet at the same time he stresses that it would be inadmissible to allow that development to change the very essence of our

Eurasia // Nature. 2015. Vol.552. P. 167-172; Peabo S. Neandertalets. V poiskakh ischeznuvshego genoma. Moscow, 2018.

2 Klein L. S. Iamnaia migratsiia i teoreticheskie iskaniia // Stratum plus. 2018. Vol. 2. P.379-387.

3 Kristiansen K. Towards a new paradigm? The Third Scientific Revolution and its possible consequences in archaeology // Current Swedish Archaeology. 2014. No. 22. P. 11-34.

${ }^{4}$ Norwegian Archaeological Review. 2017. No. 50 (2).

${ }^{5}$ Klein L. S. Iamnaia migratsiia i teoreticheskie iskaniia. P. 379-387.

${ }^{6}$ Sørensen T.F. The Two Cultures and a World Apart: Archaeology and Science at a New Crossroads // Norwegian Archaeological Review. 2017. Vol. 50 (2). P. 101-115. 
subject: the goals and methods intrinsic to archaeology — and indeed to other humanities as well - differ fundamentally from those pursued in the natural sciences. Archaeology concerns itself with material which is impossible to study and interpret from the position of the natural sciences. In this connection, it can also be added that the laws of nature do not apply to culture or society. Indeed, we do not know whether culture and society are subject to any laws at all. It is for this reason that T. F. Sørensen suggests that in the study and interpretation of archaeological materials subjective approaches and personal assessments are unavoidable. Furthermore, in his opinion, in the context of archaeological research the exact methods used by natural scientists can only be to the detriment of archaeology. They detract from archaeology's value and turn it into some kind of bed-fellow of the natural sciences.

Other scholars taking part in the discussion were not so categorical in their judgements. They adopted a more pragmatic stance ${ }^{7}$. They were not particularly concerned with the question as to which group - humanities or sciences - archaeology belongs. Nor were they unduly worried by the prospect of the sciences assuming a leading role in archaeology. The only thing that was important for them was how much benefit close collaboration with the natural sciences might bring to archaeology. If that benefit was considerable, then it would be quite wrong for scholars to reject such a collaboration. They regarded the nature of the relationship between the natural sciences and archaeology as immaterial - regardless of whether it is registered marriage, unregistered marriage or simply cohabitation.

A somewhat different approach to these issues is that adopted by L.S. Klein ${ }^{8}$. He does not support the generally accepted division between natural sciences and the humanities. In his opinion, this classification is too rigid and narrow. He does not regard archaeology merely as one of the humanities, although he accepts that its material contains cultural-historical information. This is what he has written about it: "As far as its methodological essence is concerned, archaeology is an applied science, in the same way as forensic science is. An archaeologist is an investigator (detective) who has turned up a thousand years too late at the scene of the crime" between archaeology and the natural sciences, but the marriage has to be one based on equal rights.

Many empirical archaeologists see these debates on whether collaboration between our discipline and those of natural scientists is expedient or not as idle arguments which have no practical significance. This point of view is reflected in the writings of M. Vander Linden, K. Líden and others. They are not, however, entirely correct. Not only the strategy, but also the tactics used in future archaeological research, depend upon the resolution of this issue. It is therefore hardly surprising that this question is only discussed on the pages of academic journals and not at conferences, on the Internet or in private conversations. It is, of course, first and foremost a theoretical question. This is why all those taking part in the discussion touch - to a greater or lesser degree - on this aspect of the issue. It is

${ }^{7}$ Lidén K. A Common Language is the Basis for Sound Collaboration // Norwegian Archaeological Review. 2017. Vol. 50 (2). P. 124-126; Vander Linden M. Reaction to a Reactionary Text // Ibid. P. 127-129; Fossheim H. J. Science, Scientism and the Ethics of Archaeology // Ibid. P. 116-119.

${ }^{8}$ Klein L. S. Iamnaia migratsiia i teoreticheskie iskaniia. P. 383-385.

${ }^{9}$ Ibid. P. 384. 
revealing to note that K. Kristiansen entitles his response to his opponents "The Nature of Archaeological Knowledge and its Ontological Turns"10.

In the opinion of T.F. Sørensen, the key concept in archaeology is that of the "trace". A "trace" is not direct evidence of the past, a fact from the past. It is a kind of sign from the past, which can be decoded and correctly interpreted only within the booundaries of the humanities. The invasion by natural-scientific methods into that subtle sphere can only harm archaeology, undermine faith in the "trace" and so on ${ }^{11}$. According to T. F. Sørensen, the very nature of archaeology is incompatible with such methods.

All these arguments put forward by T.F. Sørensen are regarded as pure hermeneutics by L.S. Klein. He equates the "trace" with the concept of an "archaeological source"12. He regards sources as the fundamental universals of archaeology. In his opinion, the definition of an archaeological entity, the methods employed in archaeology and its academic status depend to a large extent on the interpretation of sources. He attributes such importance to them that archaeology itself is something he considers a source-study discipline ${ }^{13}$.

This assertion by L.S. Klein is a carefully considered conclusion. He has devoted many works to substantiating it, including his well-known book Archaeological Sourc$e s^{14}$. He was the first scholar in both our and West-European archaeology to provide an extensive definition of the concept of archaeological source: "an ancient material (i. e. cultural-material) source of information; a material entity in relation to which information about its functions and cultural links and about closely related entities has either been lost or seriously damaged, making it difficult to restore (for such restoration a specific range of methods is required)"15. According to this definition, the key features of the archaeological source are its materiality and its age. L.S. Klein writes that it differs from other material sources in that it is ancient, and from other ancient sources in that it is material ${ }^{16}$. It is with these two characteristics that Klein links the distinctive dual nature of the source or - to phrase it another way - the dual information it provides. The first of these is determined by the fact that the source is an ancient entity and all its links - with both past and contemporary culture - have been broken. It is therefore outside any cultural-historical context. The second divide is predetermined by the material nature of the source. This is why the cultural-historical information within it is in a coded form. It is essential to decipher that information and transpose it into the language of the ideas and concepts of modern science. By way of conclusion L. S. Klein writes that "this dual split constitutes the main distinctive quality of archaeological sources"17.

The views expressed by L.S. Klein have become very well-known and have been actively discussed over a long period. The most topical question still remains that concerning the essence of the concept "archaeological source". In the opinion of some researchers

${ }^{10}$ Kristiansen K. The Nature of Archaeological Knowledge and Its Ontological Turns // Norwegian Archaeological Review. 2017. Vol. 50 (2). P. 120.

${ }^{11}$ Sørensen T.F. Archaeological paradigms: pendulum or wrecking ball? // Norwegian Archaeological Review. 2017. No. 50 (2). P. 130-134.

12 Klein L. S. Iamnaia migratsiia i teoreticheskie iskaniia. P. 384-385.

13 Klein L.S. Istoriia arkheologicheskoi mysli: v 2 t. T.2. St. Petersburg, 2011. P. 15-17.

14 Klein L. S.: 1) Arkheologicheskie istochniki. Leningrad, 1978; 2) Arkheologicheskie istochniki. 2-e izd., dop. St. Petersburg, 1995.

${ }_{15}$ Klein L. S. Arkheologicheskaia tipologiia. Leningrad, 1991. P. 348.

16 Klein L. S. Arkheologicheskie istochniki. Leningrad, 1978. P. 61.

17 Ibid. 
there is a serious error in Klein's definition. It presents two closely related, but nevertheless different, phenomena as one and the same: archaeological sites and archaeological sourc$\mathrm{es}^{18}$. Merging them together is inadmissible. From a gnoseological point of view, they belong to different categories and different levels of cognition. An archaeological site is, as a rule, a substantial and material object. It is given directly and objectively. Archaeological sites exist independently of us and our ideas about them. They can be represented by various kinds of artefacts, assemblages of artefacts and all manner of man-made structures (canals, fields and so on). They had taken shape in the process of human activity and are the result of human labour. They should be regarded as representations of past cultures and for that reason they are the focus of archaeologists' keenest interest. Unlike their parallels in "living" culture, however, they are deposits and devoid of any current cultural functions. During the process of being deposited most artefacts lose all links with their culture and no longer benefit from its care and protection. They are subject to the power of their natural surroundings. Those surroundings can destroy them, distort them or transform them into some kind of new formation, an example of which can be a cultural layer. They already represent a "dead" culture, which is slowly but steadily being swallowed up by Nature. The longer the impact of the natural environment lasts, the more the fossilized artefact will come to resemble a natural entity.

From the data outlined above it follows that the most important features of archaeological sites are their 'artefact nature' and 'fossilized' qualities. The second of those terms should be understood as the results of the impact exerted by the natural environment on an artefact and the part of that environment in which it is directly situated. To sum up, we may conclude that all excavated artefacts, assemblages of the latter and artificial structures can be referred to archaeological sites ${ }^{19}$. To this it needs to be added that the proposed formulations mentioned above are only the main aspects of archaeological sites. In reality, their composition includes not only artefacts but also eco-facts, nature-facts and those features which apply to cultural-natural formations.

When we move on to consider archaeological sources, it is appropriate to point out once again that they are similar to sites in a number of their characteristics. They are, however, not the same as archaeological sites. They are not tangible or material phenomena, they are not presented to us directly or objectively. This is inferential knowledge obtained as a result of the study of sites. They are not simply the content of a site, like water in a glass. They are generated during the process of investigation. Moreover, their volume, content and quality depend on the erudition and personal abilities of the researcher ${ }^{20}$. In this sense, archaeological sources are man-made and thus contain a considerable degree of subjectivism. The composition of archaeological sources can from time to time be extended and renewed.

The difference between archaeological sites and sources manifests itself at virtually all stages of archaeological procedures. These differences are recorded particularly clearly and graphically in field archaeology. They are, however, also evident at the level of more

18 Sher Ia.A. Eshche ob arkheologicheskikh istochnikakh i "zakliuchennoi" v nikh informatsii // Arkheolog: detektiv i myslitel'. St. Petersburg, 2004. P. 114-123; Belkov P. L. Etnos i mifologiia: elementarnye struktury etnografii. St. Petersburg, 2009. P.281; Bochkarev V.S. O nekotorykh kharakternykh chertakh arkheologicheskikh pamiatnikov i arkheologicheskikh istochnikov // Arkheologiia drevnikh obshchestv Evrazii: khronologiia, kul'turogenez, religioznye vozzreniia. St. Petersburg, 2014. P. 47-51.

19 Bochkarev V.S. O nekotorykh kharakternykh chertakh... P. 51.

20 Sher Ia. A. Eshche ob arkheologicheskikh istochnikakh... P. 115-121. 
theoretical investigation. Various types of sites (burials and hoards, for instance) can provide information for one and the same type of source (for example, chronology). The opposite situation is encountered just as regularly, i.e. when one and the same type of site provides information which can be used in relation to several different sources ${ }^{21}$.

It can therefore be stated that archaeological sites and sources are not identical on either an ontological or a gnoseological level. They are different. At the same time, they are inseparably linked. Archaeological sites and sources together form a pair, in which the first link plays the most important role. Archaeological sites are the objective basis for sources. It is precisely sites that determine - to a large extent - the content and special nature of archaeological knowledge. For this reason, it is appropriate to dwell on the characteristics of sites in a little more detail.

As follows from the definition adopted earlier, archaeological sites are comprised of two main components. One of them we can be rereferred to as culturological, and the other - as natural-historical. The first component consists mainly of artefacts. For that reason, it is the main supplier of cultural-historical information, the extracting and studying of which is one of the main tasks of archaeology as the discipline of the humanities. The second component includes eco-facts, nature-facts and so-called cultural-natural entities. They are all of natural origin or have took shape under a powerful impact of the natural environment, which makes it thus reasonable to regard this second component as the basis for natural-scientific repository of archaeology. It is from this repository that materials are selected for geological, paleo-botanical, paleo-zoological, chemical and other natural-scientific investigations. As pointed out by K. Kristiansen, throughout the whole history of archaeology, the range of such investigations has been steadily widening. In his opinion, this stemmed from the fact that investigations of this kind revealed new knowledge for archaeologists and extended the possibilities opening up for them.

At the same time, it should be firmly emphasized that such knowledge means little on its own without a cultural-historical context. Without that context, the knowledge has no purpose or focus. It only acquires true value and cultural-historical significance within the framework of that context. Only archaeology, however, is currently capable of reconstructing that context and adapting knowledge from the natural sciences to serve that end. The whole range of ideas and concepts of today's archaeology is directed towards carrying out that task. It has taken shape gradually over the last 150 years. What set the process in motion was Thomsen's creation of the "three-age system". This system was the first scientific paradigm for archaeology, which turned it into a separate discipline among the humanities ${ }^{22}$. Thanks to that system, concepts such as the "archaeological era" and a universal system emerged, classifying the periods to which excavated antiquities belonged. The criterion for designating these periods was an indicator of the change in technologies for working with the main materials from which antiquities were fashioned: stone, copper, bronze, iron. In connection with the declared subject of this article it is important to point out that this criterion is based on natural sciences. Over time, as more knowledge was gathered regarding ancient technologies, this criterion became more precise and concrete. The actual system for defining archaeological periods proceeded to be developed after that.

${ }^{21}$ Bochkarev V.S. O nekotorykh kharakternykh chertakh... P. 18.

${ }^{22}$ Bochkarev V.S. Kul'turogenez i drevnee metalloproizvodstvo Vostochnoi Evropy. St. Petersburg, 2010. P. 14-20. 
While Thomsen's system involved three links, now there are twice as many. It is possible that this number will increase still further in the future. New data about production techniques used for the most ancient iron in the North-Western Pontic region and the Carpathian-Danube region have made it possible to suggest that there was another (seventh) era between the "bronze" and the "iron" eras. This came to be known as the Ferraaeneum ${ }^{23}$.

In the course of archaeological research, it emerged that technological knowledge was of decisive importance for delineating Thomsen's ages within his own system. In this connection, reference can be made to an experiment to define the Bronze Age in the southern half of Eastern Europe ${ }^{24}$. This was based on the use of indicators for the composition of the metal, the construction and materials used for moulds in which bronze was cast for making shaft-hole axes and also the kind of devices used for fixing handles to metal items. Changes in these indicators, which took place at the same time, made it possible to divide the era in question into three stages: Early, Middle and Late Bronze. This gradation is independent of other kinds of periodization and is therefore objective.

In the second half of the $19^{\text {th }}$ century and with the help of stratigraphy and other methods, the reliability of Thomsen's periodization was finally demonstrated, and it was then developed further. The Neolithic and Chalcolithic eras were identified and, somewhat later, the Mesolithic era. Together with that system and also under the strong influence of Charles Darwin's theory, the idea of the progressive evolution of human culture and society came to prevail in archaeology. That idea was then to find its practical embodiment in the archaeology of the Bronze Age in Northern Europe elaborated by Oscar Montelius. It was at that time that ideas regarding archaeological assemblages, types and attributes were advanced. These ideas, together with that of evolution, provided the basis for the typological method proposed by O. Montelius. It opened up new possibilities for the study of the relative chronology of archaeological materials from those regions where there was an absence of any stratified sites. At the same time, the method also enabled to trace cultural continuity in those regions over a more or less long interval of time.

A most important event of the early- $20^{\text {th }}$ century was the discovery of the phenomenon which came to be known as an archaeological culture. On a par with the "attribute" and "type", it became one of the basic concepts in the analytical sequence in archaeolo$\mathrm{gy}^{25}$. As regards information potential, the archaeological culture is the richest and most wide-ranging link in that sequence, and with regard to its structure - the most complex. For this reason, it is placed at the top of this sequence.

The concept of an archaeological culture provided new and major possibilities for the spatial-temporal organization of material and for its cultural-historical interpretation. It is no surprise that from the outset it formed the basis for ethnic, historical, sociological and other reconstructions in archaeology. It was a focus of attention in the archaeology of the $20^{\text {th }}$ century. In European archaeology, countless books were devoted to questions

${ }^{23}$ Bochkarev V. S., Kashuba M. T. Ot bronzy k zhelezu: skachok ili poetapnyi perekhod (po materialam epokhi pozdnei bronzy - rannego zheleza Severnogo Prichernomor'ia i Karpato-Dunaiskogo regiona) // Arkheologiia vostochno-evropeiskoi stepi. 2017. Vol. 13. P. 87-112.

${ }^{24}$ Bochkarev V.S. K voprosu o periodizatsii pamiatnikov bronzovogo veka iuga Vostochnoi Evropy // Proshloe chelovechestva v trudakh peterburgskikh arkheologov na rubezhe tysiacheletii (K 100-letiiu sozdaniia rossiiskoi akademicheskoi arkheologii). St. Petersburg, 2019. P. 166-170.

25 Bochkarev V.S. K voprosu o sisteme osnovnykh arkheologicheskikh poniatii // Predmet i ob"ekt arkheologii i voprosy metodiki arkheologicheskikh issledovanii. Leningrad, 1975. P.34-42. 
concerning the origin of various archaeological cultures, their development and collapse. The first of those questions proved particularly topical. L.S. Klein even declared that the sequence of cultures one after another was the key issue in archaeology ${ }^{26}$. One of the first scholars who appreciated the tremendous potential of what was then a new concept in archaeology was Gordon Childe. It was with reference to archaeological cultures that he was able as early as 1925 to paint an impressive picture of the development of Europe in the Neolithic era and the Bronze Age ${ }^{27}$. From then on, the archaeological culture became the main "player" in all kinds of cultural-historical surveys.

In the archaeology of our country - thanks to works by A. A. Spitsin and, in particular, those by V. A. Gorodtsov - the term and concept of the archaeological culture began to be used earlier than in the research carried out in many other European countries. As early as 1916 and again with more detail in 1927, V. A. Gorodtsov succeeded in describing the Bronze Age in Eastern Europe as a totality of archaeological cultures which were interconnected and following on from one another ${ }^{28}$. Admittedly at the beginning of the 1930s, in the period dominated by so-called stadial theory, the concept of the archaeological culture - similarly to other concepts associated with traditional archaeology — was rejected in Soviet archaeology and virtually prohibited. It was not until another twenty years afterwards that a slow return to them could begin ${ }^{29}$. A little later, in the 1960s and 1970s, a fairly wide-scale discussion of the issue of archaeological cultures unfolded in our academic literature ${ }^{30}$. Apart from a few pauses, it has been continuing virtually until the present day ${ }^{31}$. L. S. Klein is constantly turning to the subject of the archaeological culture ${ }^{32}$.

${ }^{26}$ Klein L.S. Problema smeny kul'tur i teoriia kommunikatsii // Kolichestvennye metody v gumanitarnykh naukakh. 1975. Vol. 8. P.95-103.

${ }^{27}$ Childe V.G. The Dawn of European Civilization. London, 1925.

${ }^{28}$ Gorodtsov V. A.: 1) Kul'tury bronzovoi epokhi v Srednei Rossii // Otchet Imperatorskogo Rossiiskogo istoricheskogo muzeia imeni imperatora Aleksandra III v Moskve za 1914 god. Moscow, 1916. P. 121-226; 2) Bronzovyi vek na territorii SSSR // Bol'shaia sovetskaia entsiklopediia: v 65 t. 1927. T. VII. P. 610-626.

${ }^{29}$ Foss M.E. O terminakh "neolit", "bronza", "kul'tura" // Kratkie soobshcheniia Instituta istorii material'noi kul'tury. 1949. Vol. XXIX. P. 22-47; Briusov A. Ia. Arkheologicheskaia kul'tura i etnicheskie obshchnosti // Sovetskaia arkheologiia. 1956. No. XXVI. P. 5-27.

${ }^{30}$ Zakharuk Iu.N.: 1) Problemi arkheologichnoi kul'turi // Arkheologiia. 1964. No. 17. P.12-42; 2) K voprosu o prirode arkheologicheskoi kul'tury // Noveishie otkrytiia sovetskikh arkheologov: v $3 \mathrm{ch}$. Ch.3. Kiev, 1975. P. 12-14; 3) Arkheologicheskaia kul'tura: kategoriia ontologicheskaia ili gnoseologicheskaia // Vostochnaia Evropa v epokhu kamnia i bronzy. Moscow, 1976. P.3-10; 4) Paradoks arkheologicheskoi kul'tury // Problemy sovetskoi arkheologii. Moscow, 1978. P.49-54; 5) Ob odnoi kontseptsii arkheologicheskoi kul'tury // Pervobytnaia arkheologiia: poiski i nakhodki. Kiev, 1980. P.256-259; Kamenetskii I. S. Arkheologicheskaia kul'tura - ee opredelenie i interpretatsiia // Sovetskaia arkheologiia. 1970. No.2. P.18-36; Kamenetskii I.S., Marshak B.I., Sher Ia.R. Analiz arkheologicheskikh istochnikov (vozmozhnosti formalizovannogo podkhoda). Moscow, 1975. P. 152-168; Klein L. S.: 1) Katakombnye pamiatniki epokhi bronzy i problema vydeleniia arkheologicheskikh kul'tur // Sovetskaia arkheologiia. 1962. Vol.2. P. 26-38; 2) Problema smeny kul'tur v sovremennykh arkheologicheskikh teoriiakh. P.95-103; 3) Problemy preemstvennosti i smeny arkheologicheskikh kul'tur // Preemstvennost' i innovatsii v razvitii drevnikh kul'tur. Materialy metodologicheskogo seminara. Leningrad, 1981. P.33-38; 4) Problema smeny kul'tur i teoriia kommunikatsii // Kolichestvennye metody v gumanitarnykh naukakh. Moscow, 1981. P.18-23; 5) Arkheologicheskaia tipologiia. P. 125-208.

31 Bochkarev V.S. Problema kul'turno-istoricheskogo soderzhaniia arkheologicheskoi kul'tury // Mavrodinskie chteniia. Peterburgskaia istoricheskaia shkola i rossiiskaia istoricheskaia nauka: diskussionnye voprosy istorii, istoriografii, istochnikovedeniia. St. Petersburg, 2009. P. 567-571; Savinov D. G. Gumanitarnaia arkheologiia. St. Petersburg, 2019. P. 18-22.

32 Klein L.S. Arkheologicheskoe issledovanie: metodika kabinetnoi raboty arkheologa: v 2 t. T.1. Donetsk, 2012. P.272-291. 
In general, this discussion has proved a most fruitful one. It has proved possible to define in precise terms the concept of the archaeological culture and to clarify a whole series of theoretical questions. In particular, scholars have been able to justify singling out such supra-cultural concepts as groups or blocks of cultures, cultural-historical communities and regions.

In West-European research there had been no underlying reasons for rejecting the idea of the archaeological culture, attempts to reject it or to replace it with some other category - until the spread of the ideas constituting Processual (or New) Archaeology began. Intensive use was still made of the concept of the archaeological culture. Attention was focused in particular on the search for theoretical models to explain the emergence of new archaeological cultures. Hypotheses concerning migration, diffusion and evolution became particularly widespread. At one time - under the influence of Gordon Childe's works - the second of those hypotheses was highly popular. In the 1960s and 1970s, however, radio-carbon dating, which had just appeared on the horizon, dealt an unexpected and hard blow to it. A series of C14 dates showed that certain phenomena in European pre-history, which Childe considered to have been adopted from the Ancient East or the Aegean region, were of the same date or even somewhat older than their eastern parallels. These new data led Colin Renfrew to criticise Childe's diffusionist ideas and to attempt to substantiate a thesis demonstrating that the European Chalcolithic and the Bronze Age were completely autonomous. The new $\mathrm{C} 14$ chronology not only moved the beginning of those two eras back in time, but also demonstrated that they had existed significantly longer than had previously been thought. This revelation, proposed by Renfrew, obliged scholars, in its turn, to have doubts regarding the reliability of the evolutionary diagram for the development of European pre-history ${ }^{33}$.

The transition of archaeology to radio-carbon dating was referred to by Renfrew as the radio-carbon revolution. K. Kristiansen pointed out that it had been the second natural-scientific revolution in archaeology. The radio-carbon revolution did indeed have spectacular consequences. Alongside a number of other natural-scientific methods, radio-carbon dating not only altered traditional ideas and made them more precise, but also opened up totally new prospects for the discipline. There is no doubt that it was under the influence of that revolution that the new trend emerged, which came to be known as Processual Archaeology.

All these innovations were bound to have an impact on the range of concepts used in archaeological research. Overall, however, they were developed independently in accordance with their own rules. By the mid- $20^{\text {th }}$ century, the core of those concepts had taken definitive shape. All the main archaeological concepts in the natural and the analytical sequence had been identified and described. They were being broadly applied in practice. Yet few appreciated in those early days that they were closely interlinked and were parts of a single system. One of the first who understood this and applied in practice, was David Clarke in his book "Analytical Archaeology" in $1968^{34}$, which was an outstanding work regarding both its scope and importance. L. S. Klein, who is deemed among the lead-

33 Bochkarev V.S. "Radiokarbonnaia revoliutsiia" i problema periodizatsii pamiatnikov epokhi bronzy iuzhnoi poloviny Vostochnoi Evropy // Printsipy datirovaniia pamiatnikov epokhi bronzy, zheleznogo veka i srednevekov'ia. St. Petersburg, 2013. P.60-61.

${ }^{34}$ Clarke D. Analytical Archaeology. London, 1968. P. 684. 
ing theoreticians of modern archaeology, acknowledged that D. Clarke's book ${ }^{35}$ had been the initial impetus behind his "Archaeological typology". On frequent occasions, Clarke's "Analytical Archaeology" has been debated and discussed among western archaeologists. In Russian-language academic literature, Clarke's views were outlined in detail and commented on in a review by G. A. Fiodorov-Davydov ${ }^{36}$ and also in a number of works by L. S. Klein ${ }^{37}$. For this reason, we shall now dwell briefly on those ideas of David Clarke's which appear to be fundamental.

The central thesis in Clarke's theory is the idea of culture in its wide, anthropological sense. It should be emphasized that precisely culture and not society with its history is the main focus of this author. He examines culture as a complex dynamic system consisting of several sub-systems. One of the latter is material culture, the excavated remains of which are studied by archaeologists. In D. Clarke's opinion, the main task of archaeology is to explain the patterns it discovers in the process of its investigation of the material culture of the past. In this respect, Clarke follows the principles of "New Archaeology". After that he moves on to a detailed description of concepts traditional in archaeology (the attribute, artefact, type and so on), which "New Archaeology" ignored and tried not to use. David Clarke analyses these concepts in pairs in keeping with the links between them: attribute-artefact, artefact-type, assemblage-culture, culture-cultural group, cultural group-technocomplex. Each of these pairs Clarke examines as a dynamic system. In the final analysis Clarke links them all together in a stepped sequence, which he refers to as a "hierarchical model of the major archaeological entities arranged in ascending order of system complexity" ${ }^{38}$. The creation of this model can be regarded as one of Clarke's most important theoretical achievements. In it, he convincingly demonstrated the extremely close between the main archaeological concepts - their systemic character. Not one of them can be examined in isolation, separately from the others. This model is, however, not without its deficiencies. In our opinion, it is essential to introduce into it a number of clarifications and alterations ${ }^{39}$. What we cannot fail to notice is that Clarke arranged entities, which were not of equal value or of equal status, in a single uninterrupted sequence. In actual fact, it is essential to divide them into two groups. The first should include those entities which are revealed to us as objective (properties of artefacts, artefacts and assemblages of artefacts), while the second would include their abstractions, their ideal models (the attribute, type or culture). They are interlinked, but from a gnoseological point of view, they are different. For this reason, they need to be arranged not in a random way one after another - as Clarke does - but in two parallel sequences. The first of these can be called archaeology's natural sequence and the second - the analytical sequence. This two-sequence structure, however, immediately reveals that David Clarke has lost sight of another important real component - the properties of the artefact. Without those, an attribute loses its objective basis and the whole model - its equilibrium. Failure to include in the model the concept of a "property" is equivalent to depriving a type of one of its com-

${ }^{35}$ Klein L. S. Istoriia arkheologicheskoi mysli. P.271.

36 Fedorov-Davydov G. A. Poniatiia "arkheologicheskii tip" i "arkheologicheskaia kul'tura" v "Analiticheskoi arkheologii” Devida Klarka // Sovetskaia arkheologiia. 1970. No. 3. P.258-270.

37 Klein L. S.: 1) Arkheologicheskaia tipologiia. P. 194, 195, 211, 212, 214, 215, 219, 220, 324, 325;

2) Istoriia arkheologicheskoi mysli. P.229, 231, 253, 257, 258, 262, 263, 279-283, 285, 286, 293-295, 298, 301,306 .

${ }^{38}$ Clarke D. Analytical Archaeology. P. 187-189; Fig. 40.

39 Bochkarev V.S. K voprosu o sisteme osnovnykh arkheologicheskikh poniatii. P. 34-42. 
ponent elements, like the artefact. When the entities from the natural and analytical sequences are arranged in parallel, it becomes evident that these entities are inter-connected by direct and inverse links of both a vertical and horizontal nature. It is also admissible to speak of their diagonal links. In this extended and more precise form, Clarke's model acquires a genuinely systemic character. This makes it possible to provide a definition which is more valid and clearer.

The ideas expounded in our 1975 article were developed further by L.S. Klein in his book "Archaeological Typology". He proposed a more detailed classification of natural and analytical concepts in archaeology and grouped them together in a number of parallel sequences ${ }^{40}$. This meant that his model was more elaborate.

Returning now to a general appraisal of Clarke's book, we note that it aroused a stormy and far from uniform reaction in Britain. It was referred to as "Clarke's bomb". Initially, negative responses to it predominated. Moreover, it was criticized by many supporters of traditional archaeology and also by proponents of "New Archaeology". David Clarke was accused of a mechanistic approach to the values of archaeology as one of the humanities, of misusing the systemic approach, of reductionism and so on. He was also criticised for the book's poor and clumsy language. Gradually emotions subsided, and more objective assessments appeared. Now, half a century after Analytical Archaeology was first published, we can boldly assert that the book is one of the most important works on archaeology to have appeared in the $20^{\text {th }}$ century. Its author not only succeeded in bringing together all the data which had accumulated by then in relation to the concepts used in archaeology, but also revised them so that they corresponded to the needs of the modern discipline. A major step forward had been taken, which paved the way for subsequent development of archaeology.

In the earlier part of this article, we attempted to demonstrate that the development of theoretical archaeology - indeed of archaeology in general - could not be reduced to the revolutions rooted in the natural sciences described by K. Kristiansen. Our discipline had its own history and one which was more important for it. It started out with Thomsen's "three-age system", moved forward with typology expounded by O.Montelius and the conception of the archaeological culture described by Kossina and Childe, and eventually arrived at the theory outlined by David Clarke. Archaeological discoveries made in the field have a history of their own as well.

During all the various stages of its development and in all its sub-sections, archaeology was and remains one of the humanities since its main purpose continues to be the study of mankind's past. At the same time, it began from the outset to make use of the results achieved through the natural-scientific analysis of its materials. Over time, the volume of those materials was constantly growing. This was not just a question of fashion but an intrinsic need of our discipline. As has been pointed out above, the natural-historical component is an integral part of any archaeological site. It is inseparably linked with the other component - the culturological one. They cannot be separated from each other. A vivid material embodiment of the link between the two is provided by the cultural layer. Essentially, it is impossible to meaningfully investigate the two components in isolation independently of each other.

${ }^{40}$ Klein L. S. Arkheologicheskaia tipologiia. P.211-219; Fig. 25. 
As a result, the actual material we work with, its content and character assign archaeology a place at the intersection between the humanities and the natural sciences. We must assume that in the future it will develop as a multi-disciplinary subject which is first and foremost one of the humanities.

\section{References}

Allentoft M. E., Sikora M., Sjögren K.-G., Rasmussen S., Rasmussen M., Stenderup J., Damgaard P. B., Schroeder H., Ahlström T., Vinner L., Malaspinas A.S., Margaryan A., Higham T., Chivall D., Lynnerup N., Harvig L., Baron J., Della Casa P., Dąbrowski P., Duffy P. R., Ebel A.V., Epimakhov A., Frei K., Furmanek M., Gralak T., Gromov A., Gronkiewicz S., Grupe G., Hajdu T., Jarysz R., Khartanovich V., Khokhlov A., Kiss V., Kolář J., Kriiska A., Lasak I., Longhi C., McGlynn G., Merkevicius A., Merkyte I., Metspalu M., Mkrtchyan R., Moiseyev V., Paja L., Pálfi G., Pokutta D., Pospieszny Ł., Price T.D., Saag L., Sablin M., Shishlina N., Smrčka V., Soenov V.I., Szeverényi V., Tóth G., Trifanova S. V., Varul L., Vicze M., Yepiskoposyan L., Zhitenev V., Orlando L., Sicheritz-Pontén T., Brunak S., Nielsen R., Kristiansen K., Willerslev E. Population genomics of Bronze Age Eurasia. Nature, 2015, vol.552, pp. 167-172.

Belkov P. L. Ethnos and Mythology: elementary Structures of Ethnography. St. Petersburg, Nauka Publ., 2009, 281 p. (In Russian)

Bochkarev V.S. Cultural genesis and ancient metal production in Eastern Europe. St. Petersburg, Info Ol Publ., 2010, 231 p. (In Russian)

Bochkarev V.S. On some characteristic features of archaeological sites and archaeological sources. Arkheologiia drevnikh obshchestv Evrazii: khronologiia, kul'turogenez, religioznye vozzreniia. St. Petersburg, IHMC RAS Press, Art-Ekspress Publ., 2014, pp.47-51. (In Russian)

Bochkarev V.S. On the question of the periodization of the Bronze Age sites in the south part of Eastern Europe. Proshloe chelovechestva $v$ trudakh peterburgskikh arkheologov na rubezhe tysiacheletii (K 100-letiiu sozdaniia rossiiskoi akademicheskoi arkheologii). St. Petersburg, Peterburgskoe Vostokovedenie Publ., 2019, pp. 166-170. (In Russian)

Bochkarev V.S. On the question of the system of basic archaeological definitions. Predmet i ob"ekt arkheologii i voprosy metodiki arkheologicheskikh issledovanii. Leningrad, Nauka Publ., 1975, pp.34-42. (In Russian)

Bochkarev V.S. «Radiocarbon Revolution» and the Periodization Problem of Bronze Age Materials in South Part of Eastern Europe. Printsipy datirovaniia pamiatnikov epokhi bronzy, zheleznogo veka i srednevekov'ia. St. Petersburg, Institute of the History of Material Culture of the Russian Academy of Sciences Publ., St. Petersburg State University Press, 2013, pp. 59-77. (In Russian)

Bochkarev V.S. The problem of the cultural and historical content of archaeological culture. Mavrodinskie chteniia. Peterburgskaia istoricheskaia shkola i rossiiskaia istoricheskaia nauka: diskussionnye voprosy istorii, istoriografii, istochnikovedeniia. St. Petersburg, St. Petersburg State University Press, 2009, pp. 567-571. (In Russian)

Bochkarev V.S., Kashuba M.T. From bronze to iron: a leap or a gradual transition (on the materials of the late bronze age - early iron age of the northern black sea region and the Carpathian-Danube region). Arkheologiia vostochno-evropeiskoi stepi, 2017, vol.13, pp. 87-112. (In Russian)

Briusov A. Ia. Archaeological culture and ethnic communities. Sovetskaia arkheologiia, 1956, no.XXVI, pp. 5-27. (In Russian)

Childe V. G. The Dawn of European Civilization. London, Routledge \& Kegan Paul, 1925, 371 p.

Clark D. Analytical archaeology. London, Methuen Publ., 1968, 704 p.

Fedorov-Davydov G. A. "Archaeological type" and "archaeological culture" in Analytical Archeology by David. Sovetskaia arkheologiia, 1970, vol.3, pp. 258-270. (In Russian)

Foss M.E. On the terms "neolithic", "bronze", "culture". Kratkie soobshcheniia Instituta istorii material'noi kul'tury, 1949, vol.XXIX, pp. 33-47. (In Russian)

Fossheim H.J. Science, Scientism and the Ethics of Archaeology. Norwegian Archaeological Review, 2017, vol. 50 (2), pp. 116-119. 
Gorodtsov V.A. Bronze Age on the territory of the USSR. Bol'shaia Sovetskaia Entsiclopedia, vol. VII. Moscow, Sovetskaia Entsiclopedia Publ., 1927, pp. 610-626. (In Russian)

Gorodtsov V.A. Cultures of the Bronze Age in Central Russia. Otchet Imperatorskogo Rossiiskogo istoricheskogo muzeia imeni imperatora Aleksandra III v Moskve za 1914 god. Moscow, Sinodal'naya tip. Publ., 1916, pp. 121-226. (In Russian)

Haak W., Lazaridis I., Patterson N., Rohland N., Mallick S., Llamas B., Brandt G., Nordenfelt S., Harney E., Stewardson K., Fu Q., Mittnik A., Bánffy E., Economou C., Francken M., Friederich S., Pena R.G., Hallgren F., Khartanovich V., Khokhlov A., Kunst M., Kuznetsov P., Meller H., Mochalov O., Moiseyev V., Nicklisch N., Pichler S. L., Risch R., Rojo Guerra M. A., Roth C., Szécsényi-Nagy A., Wahl J., Meyer M., Krause J., Brown D., Anthony D., Cooper A., Alt K. W., Reich D. Massive migration from the steppe was a source for Indo-European languages in Europe. Nature, 2015, vol.552, pp. 207-211.

Kamenetskii I.S. Archaeological culture. Its definition and interpretation. Sovetskaia arkheologiia, 1970, no. 2, pp. 18-36. (In Russian)

Kamenetskii I.S., Marshak B. I., Sher Ia. R. Analysis of archaeological sources (possibilities of a formalized approach). Moscow, Nauka Publ., 1975, 178 p. (In Russian)

Klein L. S. Archaeological sources. Leningrad, Leningrad University Publ., 1978, 119 p. (In Russian)

Klein L.S. Archaeological sources. St. Petersburg, Farn Publ., 1995, 352 p. (In Russian)

Klein L.S. Archaeological research: archaeologist's office work technique. Vol. 1. Donetsk, Donetsk national university Publ., 2012, 622 p. (In Russian)

Klein L. S. Archaeological typology. Leningrad, Academy of Sciences SSSR Press, 1991, 448 p. (In Russian)

Klein L.S. Catacomb sites of the Bronze Age and the problem of identifying archaeological cultures. Sovetskaia arkheologiia, 1962, vol.2, pp. 26-38. (In Russian)

Klein L.S. History of Archaeological Thought. Vol.2. St. Petersburg, St. Petersburg State University Press, 2011, 688 p. (In Russian)

Klein L. S. Problems of continuity and change of archaeological cultures. Preemstvennost' $i$ innovatsii v razvitii drevnikh kul'tur. Leningrad, Academy of Sciences SSSR Press, 1981, pp.33-38. (In Russian)

Klein L.S. The problem of cultural change and communication theory. Kolichestvennye metody v gumanitarnykh naukakh. Moscow, Moscow State University Press, 1981, pp. 18-23. (In Russian)

Klein L.S. The problem of cultural change in modern archaeological theories. Vestnik Leningradskogo universiteta, 1975, vol. 8, pp. 95-103. (In Russian)

Klein L. S. Yamnaya migration and theoretical search. Stratum plus, 2018, vol. 2, pp. 379-387. (In Russian)

Kristiansen K. The Nature of Archaeological Knowledge and Its Ontological Turns. Norwegian Archaeological Review, 2017, vol. 50 (2), pp. 120-123.

Kristiansen K. Towards a new paradigm? The Third Scientific Revolution and its possible consequences in archaeology. Current Swedish Archaeology, 2014, no. 22, pp. 11-34.

Lidén K. A Common Language is the Basis for Sound Collaboration. Norwegian Archaeological Review, 2017, vol. 50 (2), pp. 124-126.

Peabo S. Neanderthal man: in search of lost genomes. Moscow, AST Publ., CORPUS Publ., 2018, 416 p. (In Russian)

Savinov D. G. Humanitarian archeology. St. Petersburg, ElekSis Publ., 2019, 94 p. (In Russian)

Sher Ia. A. More about archaeological sources and information "contained" in them. Arkheolog: detektiv $i$ myslitel'. St. Petersburg, St. Petersburg State University Press, 2004, pp. 114-123. (In Russian)

Sørensen T.F. Archaeological paradigms: pendulum or wrecking ball? Norwegian Archaeological Review, 2017, no. 50 (2), pp. 130-134.

Sørensen T.F. The Two Cultures and a World Apart: Archaeology and Science at a New Crossroads. Norwegian Archaeological Review, 2017, vol. 50 (2), pp. 101-115.

Vander Linden M. Reaction to a Reactionary Text. Norwegian Archaeological Review, 2017, vol. 50 (2), pp. 127-129.

Zakharuk Iu. N. About one concept of archaeological culture. Pervobytnaia arkheologiia: poiski i nakhodki. Kiev, Naukova dumka Publ., 1980, pp. 256-259. (In Russian)

Zakharuk Iu. N. Archaeological culture: an ontological or epistemological category. Vostochnaia Evropa $v$ epokhu kamnia i bronzy. Moscow, Nauka Publ., 1976, pp.3-10. (In Russian) 
Zakharuk Iu.N. On the question of the nature of archaeological culture. Noveishie otkrytiia sovetskikh arkheologov. Part 3. Kiev, [s. n.], 1975, pp. 12-14. (In Russian)

Zakharuk Iu. N. Problems of archaeological culture. Arkheologiia, 1964, no. 17, pp. 12-42. (In Russian)

Zakharuk Iu. N. The paradox of archaeological culture. Problemy sovetskoi arkheologii. Moscow, Nauka Publ., 1978, pp. 49-54. (In Russian)

Статья поступила в редакцию 20 апреля 2020 г.

Рекомендована в печать 12 марта 2021 г.

Received: April 20, 2020

Accepted: March 12, 2021 